\title{
Faculty of Geology, Geophysics and Environmental Protection
}

\author{
AGH University of Science and Technology, Kraków, Poland
}

The history of Faculty of Geology, Geophysics and Environmental Protection starts simultaneously with establishment of the Academy of Mining in 1919 (currently AGH University of Science and Technology). First geological departments were initially located within the structures of the Faculty of Mining:

- Department of Mineralogy and Petrography organized by Prof. Józef Morozewicz in 1919;

- Department of General Geology and Palaeontology created in 1920 and led by Prof. Walery Goetel (in 1926 reorganized into Department of General Geology);

- Department of Applied Geology created in 1921 by Prof. Karol Bohdanowicz (led by him until 1935).

At that time, teaching in geology was led by mineralogists: Józef Morozewicz (1865-1941), Stefan Kreutz (1883-1941), Zygmunt Rozen (18771944), Walery Goetel, Andrzej Bolewski (19062002), paleontologist Jan Jarosz (1877-1944), and geologists: Edward Windakiewicz (1858-1942), Tadeusz Boheński (1901-1958), Adam Drath (1904-1942) and Zygmunt Mitera (1903-1940). These professors and doctors laid the foundations of the new Faculty of Geology and Survey formed after the World War II .

The World War II left a meaningful imprint on Polish science and education. Several employees of the Academy of Mining participated in 1939 September Campaign. The universities have been closed. On November $6^{\text {th }}, 1939$, a group of 183 academics from Kraków, including 21 professors and lecturers from the Academy of Mining, were arrested and sent to Sachsenhausen concentration camp. Among the arrested were three geologists: Andrzej Bolewski, Stefan Czarnocki and Stanisław Jaskólski.
After the World War II, educational and scientific activity of the Academy of Mining and Metallurgy was reorganized into new faculties and departments. In 1946, most of geological departments previously located in the Faculty of Mining were included in a newly formed Faculty of Geology and Survey. The establishment of the Faculty of Geology and Survey was an achievement of yet another magnificent geologist - Stefan Czarnocki (1876-1947) who was the first Dean. After his death, the position had been taken over by Wojciech Rogala.

In 1948 the Department of Applied Geology was split into two distinct parts: the Department of Applied Geology I and the Department of Applied Geology II. This was initiated by Karol Bohdanowicz, a magnificent Polish geologist and miner who had been working in the Mining Academy since the beginning. The ore deposit geology was thought by him to be the basic discipline necessary for rapidly developing mining industry in Poland.

In 1951 the Faculty of Geology and Survey split into the Faculty of Survey and the Faculty of Prospecting Geology. The latter become the Faculty of Geology, Geophysics and Environmental Protection in 1992.

The Faculty of Geology, Geophysics and Environmental Protection is celebrating the $70^{\text {th }}$ anniversary. It is a big, strong and one of the leading faculties at the AGH University of Science and Technology (formerly Academy of Mining and Metallurgy). The Faculty graduates are the highest ranked experts of traditional and modern branches of national industry i.e. in geology, geophysics, hydrogeology, engineering geology, ore geology, environmental protection, in raw mineral resources and energetics. Scientific research 
carried out in the Faculty includes applied geophysics, modern knowledge on fossil fuels and renewable energy sources, ore deposit geology with particular interest in critical elements, mining geology, hydrogeology and engineering geology, mineralogy and geochemistry, geoinformatics, geotourism and many other.

The 70 years of its activity and greatness the Faculty owes primarily to the people: dedicated employees, magnificent professors, ambitious and creative students. The Faculty owes its high rank to scientific and educational collaboration with numerous institutions from all over the World and to cooperation with Polish mining industry.

The anniversary is a chance to go back to the past days and memories, to recollect great events and wonderful people. It is also a reason to share a satisfaction and pride that together we comprise such a strong and significant academic community.

Dean of the Faculty of Geology, Geophysics and Environmental Protection Prof. Adam Piestrzyński 